\title{
Investigation into Improvement of Teacher Autonomy and Student Autonomy through Collaborative Action Research*
}

\author{
Lina Guan \\ Sichuan University of Arts and Sciences, Dazhou City, Sichuan Province, 635000, China
}

\begin{abstract}
Teacher autonomy and student autonomy are interrelated and can't be divided. Collaborative action research can improve EFL teachers' professional development; renew their conception about the collaboration and change their fixed conception about teaching and learning.
\end{abstract}

Index Terms - collaborative action research, teacher autonomy, student autonomy

\section{Collaborative ACtion ResearCh}

Kemmish \& MaTaggart(1990) put forward that combination of action and research showed the basic characteristics of action research, which meant people could verify their ideas in practice in order to increase teaching knowledge and improve themselves and people could improve classroom teaching and have a better understanding of teaching philosophy. Mckerman(1998) believed that action research was the self-reflection inquiry to use the scientific methods to solve course problems and participants were the masters of this critical reflective inquiry process and reflective inquiry outcome. Action research itself is not a theoretical system, but a method to study and solve problems. It should be a tool for practitioners to study and solve problems. If language teachers want to become the active participants and central actors in curriculum implementation and development and want to truly master a set of skills in curriculum design, curriculum monitoring and curriculum evaluation, the first prerequisite is to learn to reflect on their professional activities, and on this issue, action research is indispensable. Action research can turn teachers into researchers and EFL teachers can use it to combine theory with practice. Doing action research should be based on specific situation and specific context and should attach importance to cooperative observation and research activities. It means participating in teaching practice activities and carrying out self-assessment on teaching practice activities. The basic procedures for selecting and developing action research subjects are the following: research objectives; research subjects; research focus; research results; research methods; time arrangement; research sources of information and fine-tuning. The following methods can be used in teacher action research: written reports, observation, interview, questionnaires, case study and evaluation, etc.

\section{TEACHER AUTONOMY AND STUDENT AUTONOMY}

Teacher autonomy means that teachers have the ability to teach independently, or have the ability, freedom or responsibility to choose the teaching issues related to themselves. Little (1995) believes that teacher autonomy is a kind of ability to conduct independent professional teaching behavior. Teachers have a strong sense of personal responsibility for teaching practice through reflection and analysis, and control the teaching process emotionally and cognitively. Tort-moloney (1997) holds that teacher autonomy is a kind of ability for independent professional development and Anderson(1987) believes that teacher autonomy is a kind of ability to get rid of the constraints on professional behavior and professional development. Student autonomy means that students should be aware of their own responsibility for their learning, and implement this responsibility in all aspects of the learning process through participation, planning, evaluation, etc. An autonomous learner is a successful learner, and theoretically learner autonomy can be developed in any plan organized. Teacher autonomy and student autonomy are interrelated and interdependent, just like two sides of the same coin. For students, teachers are no longer the authoritative ones, but the helpers, consultants and managers of learning resources. Student autonomy depends on teacher autonomy, and when students develop the autonomous studying ability, teaching has become the research and research has become the teaching. The teachers themselves turn into earners, and also are working on autonomous learning. Teachers feel to be given more rights to manage and control their teaching behavior and teachers also get self-development.

La Ganza (2009) put forward the Dynamic Interrelation Space Theory (DIS Theory) between teacher autonomy and student autonomy in 2009. Dynamic Interrelation Space Theory includes teacher dynamic development mode, which

* Funded by Teaching Research and Reform Project of Sichuan University of Arts and Sciences "Research on Current Condition of EFL Teachers' Critical Thinking Based on Theory of Autonomy"(Project Code: 2020JY048) 
contains $\mathrm{T}+$ and $\mathrm{T}$ - development modes, and student dynamic development mode, which contains $\mathrm{L}+$ and $\mathrm{L}-$ development modes. T+ means the stage in which the teacher seeks to influence students' learning and learning experiences in an active way, while $\mathrm{T}$ - means the cognitive and emotional stage in which the teacher influences students' learning and learning experiences in a negative or passive way. L+ refers to the stage in which learners actively seek and hope for the teacher's influence and help on their learning and learning experiences. L- represents the stage of cognitive emotion in which learners refuse to seek and obtain the teacher's influence on their learning and learning experiences. This continuous interaction constitutes a dynamic system and produces four dynamic patterns: Q1: T+L+; Q2: T - L +; Q3: T - L -; Q4: T + L -. Q1 model shows that the teacher influences learners' learning and learning experiences in a positive and active way, while students actively accept the teacher's help and influence.Q2 model shows that teacher helps learners in a passive way, while learners want to get the teacher's help and guidance. Q3 mode indicates that teacher gives learners the passive help, while learners want to complete their study independently and have more rights of autonomy. Q4 mode indicates that teacher wants to help students actively, while students want to finish their study independently. DIS Theory indicates that this interactive mode of autonomous learning will be more likely to produce between the student and a certain teacher, and will not be likely to produce between the student and the other teachers. Only when the teacher and the student actively interact with each other, the teacher's teaching and student's learning can become meaningful and teacher's independent teaching and student's autonomous learning can be achieved. In fact, learner autonomy includes two aspects: one is the autonomy gained by the students who have the helpful and beneficial interaction with the teacher, and the other is the autonomy gained by the students after completing their own learning independently.

\section{RESEARCH PROCEDURES AND RESEARCH METHODS}

\section{A. Research Purpose}

1. How does cooperative action research affect the professional development and competence of in-service teachers?

2. How does cooperative action research affect the teaching concept and teaching ability of student teachers?

\section{B. Objects of Research}

The objects of this research are five EFL in-service teachers and five student teachers who are from Sichuan University of Arts and Sciences in Sichuan province in China. Among five in-service teachers there are three females and two males. Five in-service teachers have taught English for more than ten years and have got master degrees of English major. Among them two teachers teach English listening course and two teachers teach spoken English course and one teacher teaches English writing course. Five in-service teachers are classified as in-service teacher A, in-service teacher $\mathrm{B}$, in-service teacher $\mathrm{C}$, in-service teacher $\mathrm{D}$ and in-service teacher $\mathrm{E}$. Five student teachers are senior undergraduate students of English major from Sichuan University of Arts and Sciences and they intern in the same middle school. These five student teachers volunteer for the research and participate in the cooperative classroom action research with five in-service teachers and they are classified as student teacher F, student teacher $\mathrm{G}$, student teacher $\mathrm{H}$, student teacher I and student teacher J.

\section{Research Methods}

The cooperative action research lasted one semester. In the first week of the semester, five in-service teachers would learn about action research theory and research methods and shared the information with five student teachers. Then they discussed the steps of doing research together, which included problem-finding, data collection, data analysis and tools for data collection, etc. One in-service teacher and one student teacher formed a research group on a voluntary basis. In-service teachers would share the research tasks with student teachers, and in-service teachers would undertake the research tasks of data analysis. They discussed their roles and responsibilities in the action research in a cooperative way. They initially decided that in-service teachers should find the research topics, and then designed the research plans together with the student teachers. The student teachers were responsible for collecting data and preparing for research reports. After careful discussion, five research groups identified the following classroom research topics: Research Group 1 (in-service teacher A and student teacher F): How to increase students' interest in English writing class? Research Group 2 (in-service teacher B and student teacher G): How to increase the chances of oral English communication in and out of class? Research Group 3 (in-service teacher C and student teacher H) : How to use English drama to help English learners learn English? Research Group 4 (in-service teacher D and student teacher I) : How to make full use of students' anxiety in English listening class? Study Group 5 (in-service teacher E and student teacher J) : How does motivation affect students' learning for English?

Research data collection mainly comes from two aspects, one is the interviews with the in-service teachers, the other is the research diaries written by the student teachers. Since the in-service teachers were willing to share their feelings, the author and the in-service teachers met in groups or individuals every two weeks to get to know the progress of cooperative action research through interviews, discussion or emails. Student teachers were required to keep the detailed records of the whole process of conducting cooperative action research with in-service teachers. They should write at least one research journal every week, in which they should elaborate on their thoughts and feelings about 
participating in classroom action research and how they cooperated with in-service teachers. The author made a detailed record of each meeting.

\section{RESEARCH RESULTS AND ANALYSIS}

\section{A. Action Research Promotes the Professional Self-development of In-service Teachers and Student Teachers}

Teachers' self-monitoring ability is regarded as one of the ways in which teachers can develop and strengthen their teaching practice, and it plays an important role in the process of self-leadership in their teaching. In-service teachers generally believe that teachers' self-monitoring ability improves during the study of cooperative action research. For example, in-service teacher A said: "In order to adjust the content of the class, I must maintain the sensitivity to students' reaction and answer. In my spoken English class, it's almost impossible to carry out teaching in accordance with the original teaching plan, because I must increase, cut and adjust my teaching content according to students' reaction and answer in the class. After discussing with student teacher F, we changed some of the original material contents and made it more suitable for students' current learning level." In-service teacher E said: "Now I look for appropriate classroom teaching activities every day. I can find problems, collect relevant information, find solutions and practice them again. I feel teaching is much more interesting than before".

Teachers' professional development is a continuous process of learning, discovering and using their own potentials in their teaching behaviors. This process requires teachers to find good teaching methods based on their own teaching experiences, teaching concepts and understanding of the classroom. In-service teachers generally believe that their professional abilities have been developed and improved by changing their usual teaching practices and taking risks to do different things or trying new ideas and teaching methods. In-service teacher B said: "When I discussed with the student teacher $\mathrm{G}$ about using drama to enhance students' interest and improve their English levels, I was not completely sure about the teaching result, because time was limited, but the teaching result was beyond my expectation. The students were very active in participating, and the original play was adapted quite well by them. Students' performance was very good in two hours of performing. Some students who were quite shy in the class could actively participate in it boldly and classroom atmosphere was very warm. The teaching skill that teachers will learn about is to depend on their immediate performance in the class according to the students' responses, and students in the English drama performance made good use of this chance given by the teacher and the effect was quite good."

The research reports of the student teachers also reveal that participating in the research has enriched their knowledge and ability. The reports of three student teachers all showed that participating in the research had improved their current knowledge levels. Student teacher F said: "In the process of teaching, I read many articles about writing, and it gave me a chance to focus on a certain research topic. Writing a research report also had greatly improved my writing skills and level in English and I could use the writing skills learned in class. I also understood many difficulties the teachers were facing. If students and teachers can communicate with one another so often, it can improve the bilateral activities of teaching and learning". Almost all the student teachers have showed that the knowledge gained from participating in the action research will be of great help to their future teaching careers. Student teacher H said: "I had thought that doing research was a very complicated thing, as a student I couldn't do it, but the fact had proved that this was not what I used to think. The cooperative action research with my teacher has helped me complete my graduation thesis better and let me have confidence for the future career. I like studying with the teachers because we are ready to help one another".

\section{B. Cooperative Action Research Promotes the Cooperative Development of In-service Teachers and Student Teachers}

Usually the professional isolation exists among college teachers. When teachers do the research, it is easy to be limited in the reflection of their own teaching processes and teachers cannot see the reflection or research results of others. Professional isolation is a major obstacle to teachers' professional development, and there is little cooperation and communication between foreign language teachers. The relative isolation of foreign language teachers from professional literature also affects their sustainable professional development to some extent. Teachers' development involves understanding their own teaching, analyzing teaching behaviors, concepts and principles, and sharing teaching experiences and results with colleagues, i.e. participating in cooperation. In-service teachers and student teachers involved in the cooperative action research have affirmed the value of this cooperation. In-service teachers E said:" When I just worked with student teacher J, he looked a bit stiff. When it came to the difficulties of middle school students' English writing, he mentioned a lot of worry and anxiety in his English writing training and he expectations of the students for English writing teachers. I was shocked because I had always followed the writing textbook step-bystep, and he played a very important role in helping me collect data and feedback information from students, because in a way, the data he collected was more authentic and credible than what I got". In-service teacher D said: "It is quite difficult for college teachers to write articles for getting higher professional titles. However, in this study, I found many research topics and many materials to do research through cooperation with the student teacher I, which made me think it was not so difficult to write articles". In-service teacher C said: "Without the help of the student teacher H, I could not find a proper questionnaire for my research topic. She helped me find a lot of relevant research materials, which saved me a lot of time".

Student teacher F said "As a student teacher to intern in the middle school, teaching English writing is a very difficult thing. In the process of helping in-service teacher A collect survey data about interest for English writing class, I knew a 
lot of students' concerns, worries and demands about English writing class. We recorded these data, studied the problems and made corresponding solutions. According to the current English level of the students in the class, we discussed and determined the teaching objectives to be achieved in the writing course of this semester. After studying the writing materials involved, we found two English writing methods, namely English Process Writing Method and Long Writing Method. We worked out the teaching steps together in detail, and then I began to try to use these two teaching methods in my class, and made some small adjustments according to the actual English level of the class. The cooperative teaching with in-service teacher A makes me have different understanding for teaching. I can ask him for advice about the new problem I met in teaching at any time. I feel more confident in my teaching." Student teacher I said "The cooperative research topic between in-service teacher D and me is about the students' anxiety in English listening class. I always felt very nervous during the English listening class because I was always afraid that I couldn't understand what I had heard and couldn't answer the teacher's question. In-service teacher D told me that anxiety was not always a negative factor. For example, the facilitative anxiety would encourage people to enhance competitiveness and strive to achieve the goal, which was a positive and reasonable psychological factor. Therefore how to promote the facilitative anxiety and reduce the debilitative anxiety is my research focus and I want to try to change the debilitative anxiety into the facilitative anxiety. I want to have a good cultivation of the facilitative anxiety in my class and apply it in my class. Before the cooperation with in-service teacher D, I have been embarrassed to tell the others I have anxiety for English listening. After communicating with him, I feel relaxed a lot and the psychological burden is also reduced a lot. I think that cooperation between teachers and students is beneficial for students. If I can have the opportunity to communicate with teachers earlier, I think my listening ability will be improved more."

\section{Cooperative Action Research Promotes In-service Teachers' and Student Teachers' Autonomous Development}

Most of in-service teachers have taught English for many years and usually have the fixed views on the teaching process and tend to choose the relatively safe and eclectic ways of teaching instead of innovating. During the process of the cooperative action research, after reading a lot of relevant articles, in-service teachers have more understanding of the process for foreign language teaching than before and at the same time they begin to use this understanding to improve classroom teaching quality. Doing research for the teaching becomes a kind of tool to get the professional development and teachers have also increased the confidence to change the teaching modes, which promotes not only the quality of classroom teaching but the personal quality. Working with students has also changed teachers' inherent views on students. In-service teachers generally believe that doing research can help them better understand and respect students and accept their differences. In-service teacher $\mathrm{C}$ said: "The research enables me to understand the needs of students, and I will adjust the actual use of classroom teaching materials according to the needs, such as adding, supplementing and deleting some chapters and contents, so that I can have a flexible control over the disposal of teaching materials, instead of relying heavily on teaching materials as before. The teaching methods are more diversified than before because of the communication with students, which can provide students with more materials to meet their needs than before. Giving students the opportunities to express their needs can promote students' autonomy in learning." In-service teachers A said: "The more I know about the students, the more I can be involved in the students' world. When the interaction between teachers and students has increased, the teaching has become much easier than before, for example, I will explain the difficult part of classroom teaching contents in detail and arrange students the simple learning tasks to do after class. I will be mainly responsible for answering questions, supervising them and checking them, so that teachers will not be trapped in heavy teaching tasks all day long and students will have more independent rights to study and develop their own learning ability."

Student teacher J said: "In this term I have learned a lot from the cooperation with in-service teacher E. Our research topic is how the motivation affects students' learning. I used to think the learning motivation was the learning interest, but when I collected information about the learning motivation in the class I was teaching, I learned about a lot of different learning motivations. I tried to connect the students' English levels with their actual learning motivations and tried to analyze the deep reasons that led to these learning motivations because I wanted to find some kind of the learning law about it. Although at the end of the semester I didn't find the clear answers, I was surprised to find that I began to slowly reflect on my previous learning experience and began to learn how to collect research data and find problems and try to solve these problems." Student teacher G said:" Our research topic is how to increase the chances of oral English communication in and out of class. In China, English learned by students is often called "mute English" because they are unwilling or unable to speak English. After discussing with in-service teacher B, I made a simple survey in the class where I practiced. First I wanted to find the reasons why the students were unwilling to speak English, and then tried to put forward some solutions. In-service teacher B suggested that I should improve the students' interest in speaking English, so I applied to the school to have two English lessons in the school lab every two weeks, and I launched a "Chinese Good Stories" oral English contest among the senior students of the middle school based on the students' enthusiasm for the Internet. Scores of English final exams would include the results of this oral contest and every class for senior grade would choose one student to become the student judge. Surprisingly the students all took part in the contest actively and many students began to speak English in the class. I think the discussion and negotiation with in-service teacher B is of great help to me, a novice teacher. I love such collaboration because it helps me understand and discover the core of the problem to be solved." 


\section{CONCLUSION}

The research shows that participating in cooperative action research is beneficial to the professional development of in-service teachers, because the research broadens their horizons and makes them realize the value of cooperation and encourages them to try new teaching practices. During the cooperation, student teachers can have the opportunities to learn from their teachers and master the basic skills and methods of doing classroom research, and can share the teaching experiences with in-service teachers. They can learn how to collect data and analyze them with theory and practice. Participation in cooperative action research enables in-service teachers and student teachers to become active designers of teaching and research and they can benefit from it.

\section{REFERENCES}

[1] Anderson, L, W. (1987). The decline of teacher autonomy: tears or cheers? International Review of Education, 33, 357-373.

[2] Bartlett,L.(1990). Teacher development through reflective teaching. In Richards, J.C. \& Nunan, D. (Eds.) Second Language Teacher Education, Cambridge University Press,202-214.UK.

[3] Little, D. (1995). Learning as dialogue: The dependence of learner autonomy on teacher autonomy. System 23/2,175-182.

[4] Nunan,D. (1990). Action research in the language classroom. In Richards, J.C. \& Nunan, D. (Eds.) Second Language Teacher Education, Cambridge University Press,62-82.UK.

[5] Tort-Moloney, D. (1997). Teacher autonomy: A Vygotskian theoretical framework. CLCS Occasional Paper No.48. Dublin: Trinity College, CLCS.

[6] Wallace, M. (1998). Action Research for Language Teachers .Cambridge University Press .UK

[7] William La Ganza. (2009). Learn autonomy- teacher autonomy: Interrelating and the will to empower in Terry Lamb \& Hayo Reinders Learner and Teacher Autonomy Concepts, realities and responses, John Benjamins Publishing Company. Netherlands.

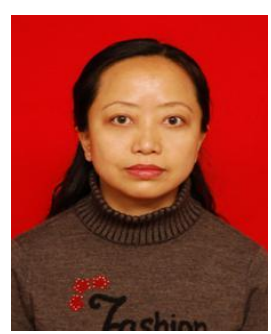

Lina Guan was born in Dazhou city, Sichuan province, China in 1972. She received her Master Degree in English Language Teaching from Western China Normal University, China in 2008.

She is currently an associate professor in the School of Foreign Language, Sichuan University of Arts and Sciences, Dazhou city, China. Her research interests include EFL acquisition and EFL teachers' development. Ms. Guan is a member of Sichuan Province Social Sciences League in China. 